\title{
Linking direct and indirect pathways mediating earthworms, deer, and understory composition in Great Lakes forests
}

\author{
Nicholas A. Fisichelli • Lee E. Frelich • \\ Peter B. Reich • Nico Eisenhauer
}

Received: 14 May 2012/Accepted: 19 November 2012/Published online: 12 December 2012

(C) The Author(s) 2012. This article is published with open access at Springerlink.com

\begin{abstract}
Ahistorical drivers such as nonnative invasive earthworms and high deer densities can have substantial impacts on ecosystem processes and plant community composition in temperate and boreal forests of North America. To assess the roles of earthworm disturbance, deer, and environmental factors in the understory, we sampled 125 mixed temperate-boreal forest sites across the western Great Lakes region. We utilized structural equation
\end{abstract}

Electronic supplementary material The online version of this article (doi:10.1007/s10530-012-0350-6) contains supplementary material, which is available to authorized users.

N. A. Fisichelli · L. E. Frelich · P. B. Reich .

N. Eisenhauer

Department of Forest Resources, University of Minnesota, 1530 Cleveland Avenue North, St. Paul, MN 55108, USA

N. A. Fisichelli ( $\square)$

Department of Silviculture and Forest Ecology of the Temperate Zone, Georg-August-Universität, Büsgenweg 1, 37077 Göttingen, Germany

e-mail: nfisichelli@gmail.com

P. B. Reich

Hawksbury Institute for the Environment, University of Western Sydney, Penrith, NSW 2753, Australia

N. Eisenhauer

Institute of Ecology, University of Jena, Dornburger Str. 159, 07743 Jena, Germany modeling (SEM) to address the hypothesis that earthworm disturbance to the upper soil horizons and selective herbivory by deer are associated with depauperate understory plant communities dominated by graminoid and nonnative species. Evidence of earthworm activity was found at $93 \%$ of our sites and $49 \%$ had high to very high severity earthworm disturbance. The SEM fit the data well and indicated that widespread nonnative earthworm disturbance and high deer densities had similar magnitudes of impact on understory plant communities and that these impacts were partially mediated by environmental characteristics. One-third of the variation in earthworm disturbance was explained by soil $\mathrm{pH}$, precipitation, and litter quality. Deer density and earthworm disturbance both increased graminoid cover while environmental variables showed direct and indirect relationships. For example, the positive relationship between temperature and graminoids was indirect through a positive temperature effect on deer density. This research characterizes an integrated set of key environmental variables driving earthworm disturbance and deer impacts on the forest understory, facilitating predictions of the locations and severity of future change in northern temperate and boreal forest ecosystems.

Keywords Carex pensylvanica $\cdot$ Climate $\cdot$ Deer browsing · Earthworm invasion · Forest soils · Graminoid cover · Invasive plants · Understory plant community 


\section{Introduction}

Nonnative earthworms and overabundant deer have been described as influential ecosystem engineers and keystone species (McShea and Rappole 1992; Hendrix and Bohlen 2002; Bohlen et al. 2004). In northern temperate and boreal forests of North America, these species are associated with a plethora of impacts that lead to significant changes in soil properties and processes and understory plant community composition (Côté et al. 2004; Frelich et al. 2006; Eisenhauer et al. 2007). Although the likely pathways of introduction for nonnative earthworms (Gundale et al. 2005; Holdsworth et al. 2007a) and impacts of deer on plant performance (Rooney and Waller 2003) are well documented, the direct and indirect relationships among earthworm disturbance, deer, environmental variables, and understory plant composition are less well understood.

Northern temperate and boreal forests in North America developed over most of the past 10,000 years, since the last Pleistocene glaciation, in the absence of large invertebrate decomposers, namely earthworms (Lumbricidae) (James and Hendrix 2004). The most common nonnative earthworms in northern forests are peregrine European lumbricids, including Dendrobaena octaedra, Aporrectodea caliginosa, Lumbricus rubellus, and Lumbricus terrestris (Hendrix and Bohlen 2002). Nonnative earthworms impact the physical, chemical, and biological properties of the forest floor (Bohlen et al. 2004; Edwards 2004). Changes to the soil environment, for example consumption of leaf litter at the soil surface and incorporation into deeper mineral soil horizons, can be regarded as disturbance with its severity varying with earthworm species identity and density (Hendrix et al. 2008; Eisenhauer 2010).

The presence of nonnative earthworms is strongly associated with human activities and infrastructure, such as timber harvesting, forest roads, cabins, and fishing areas (Hendrix and Bohlen 2002; Gundale et al. 2005; Holdsworth et al. 2007a). Once introduced, site level climate, physical and chemical soil properties, and food quality are likely to determine population success and thus level of disturbance (Edwards 2004; Curry 2004). Earthworm activity is limited by extreme temperatures and drought stress (Curry 2004). Soil characteristics, especially $\mathrm{pH}$ and texture, influence earthworm abundance. Soil $\mathrm{pH}<4.5$ is inhibitory to many earthworm species (Nordström and Rundgren 1974; Curry 2004) and since soils in northern forests often have $\mathrm{pH}$ values at or below 4.5, this factor may be a key to the severity of invasion. In addition to soil characteristics, leaf litter quality is a strong driver, with earthworm abundance positively associated with litter nitrogen and calcium (Reich et al. 2005). Northern forests contain a diverse mixture of broadleaf and needleleaf species and thus litter quality can vary sharply. Although all these factors are known to influence the composition and population density of earthworm communities, their relative roles in determining earthworm disturbance severity across large regions are unknown.

Aboveground, selective foraging by high density herbivore populations, such as white-tailed deer (Odocoileus virginianus), can have strong impacts on the composition and performance of plants in the understory (Alverson et al. 1988, McShea and Rappole 1992, Fisichelli et al. 2012a). Within the Great Lakes region of North America, white-tailed deer densities are roughly 2.5-5 times higher than prior to European settlement (Rooney and Waller 2003). Chronic herbivory and earthworm disturbance have both been associated with understory transitions from a diverse multi-layered community with high cover to a simple community dominated by just a few species (Côté et al. 2004; Edwards 2004; Rooney 2009). Such changes are likely the result of shifts in competitive interactions among plant species due to changes in seedbed conditions and soil nutrient availability associated with earthworm disturbance and selective herbivory by deer (Scheu 2003; Côté et al. 2004). Specific shifts include an increase in the cover of graminoids, especially the native though invasive mat forming sedge Carex pensylvanica, and nonnative species such as Rhamnus cathartica (Wiegmann and Waller 2006; Holdsworth et al. 2007b). High graminoid cover and reductions in preferred herbaceous species may also increase browse pressure on remaining tree seedlings (Côté et al. 2004).

The objective of this study was to examine the direct and indirect relationships among nonnative earthworm disturbance, overabundant deer, invasive plants, and environmental variables driving forest understory communities. To provide a degree of standardization, we focused on mesic mixed conifer-hardwood stands. We hypothesized that summer temperature, annual precipitation, soil $\mathrm{pH}$, and litter quality influence the 
level of earthworm disturbance severity. In addition, we hypothesized that earthworm disturbance and deer population density would increase the cover of graminoid species and deer browse damage to seedlings. These findings will broaden our understanding of the causes of earthworm invasion disturbance across the northern forest landscape and the relative roles of overabundant deer and earthworms in driving the understory plant community.

\section{Methods}

Forest plots were sampled at 125 forest sites in Minnesota, Wisconsin, and Michigan, U.S.A. Sites were initially selected for a study of tree regeneration patterns in mixed temperate-boreal forests (Fisichelli et al. 2012b) and thus all sites included a mixture of temperate broadleaf and boreal conifer species in the overstory. The most abundant tree species were Abies balsamea, Acer rubrum, Acer saccharum, Betula papyrifera, Picea glauca, and Populus tremuloides. Study sites were typical of stands across the region, generally of second-growth origin from harvesting activities 70-100 years ago, and were free from signs of recent disturbances, especially logging and fire, that might mask the impacts of deer and earthworms on upper soil and understory plant community characteristics. Sites were generally mesic in quality, on glacial till with moderately to well-drained soils ranging in texture from loamy sands to clay loams.

The climate of the region varies from dry continental in the west to lake moderated cool and wet in northeastern Minnesota and northern Michigan. Annual precipitation $(655-986 \mathrm{~mm})$ increases from west to east and mean annual temperature (2.5-5.6 ${ }^{\circ} \mathrm{C}$ ) from north to south. Mean summer temperature (JJA, $15.8-19.4{ }^{\circ} \mathrm{C}$ ) has a more complex pattern with increasing temperatures from north to south in Wisconsin and Michigan and increasing temperatures from northeast to southwest in Minnesota. Climate data (30 year averages, 1978-2007) for each study site were extracted from PRISM $4 \mathrm{~km}^{2}$ resolution climate surfaces (Daly et al. 2008).

Variables at forest sites were sampled during the growing season (June-August) 2008-2010 (Table 1) and each site contained on average $3-4$ plots $10 \mathrm{~m}$ in radius and spaced at $50 \mathrm{~m}$ intervals (456 plots altogether). Tree species basal area was measured for all live stems $\geq 10 \mathrm{~cm}$ diameter $1.3 \mathrm{~m}$ above ground level (dbh) within the entire plot. Because leaf litter quality has been shown to strongly relate to the earthworm community at a site (Holdsworth et al. 2008), we used total conifer basal area as a surrogate for litter quality. Browse pressure, mainly from white-tailed deer (Odocoileus virginianus), was assessed in each plot for maple stems (Acer spp.) on a four point scale based on the proportion of twigs browsed on saplings $0.25-2.0 \mathrm{~m}$ in height (index $=0$ : no browse, index $=1:<33 \%$ twigs browsed, index $=2: 33-67 \%$ twigs browsed, index $=$ 3:>67 \% of twigs browsed) (Frelich and Lorimer 1985). Maples were present at all sites and thus provide a standardized measure of browse pressure across the region. In addition to plot level browse pressure, we used deer population density estimates from state deer management units $\left(\sim 1,000 \mathrm{~km}^{2}\right)$ as a surrogate for summer grazing pressure on herbaceous species (MI DNR 2006; MN DNR 2009; WI DNR 2010). Percent cover of the graminoid plant functional group (Poaceae,
Table 1 Summary information for variables at northern forest study sites

\begin{tabular}{llcll}
\hline Variable & Units & Mean (SD) & Min & Max \\
\hline Conifer overstory basal area & $\mathrm{m}^{2} \mathrm{ha}^{-1}$ & $8.15(5.42)$ & 0 & 40.73 \\
Total overstory basal area & $\mathrm{m}^{2} \mathrm{ha}^{-1}$ & $28.47(7.03)$ & 10.62 & 71.01 \\
Soil pH & & $4.59(0.44)$ & 3.14 & 5.87 \\
Annual precipitation & $\mathrm{mm}$ & $777(65)$ & 655 & 986 \\
Mean summer temperature & ${ }^{\circ} \mathrm{C}$ & $17.8(0.7)$ & 15.8 & 19.4 \\
Graminoid cover & $\%$ & $5.8(8.8)$ & 0 & 45 \\
Browse pressure & $0-3$ index & $2.3(0.8)$ & 1 & 3 \\
Deer population density & Deer km & $6.3(2.8)$ & 2 & 15 \\
Organic soil $\left(\mathrm{O}_{\mathrm{e}}\right.$ and $\left.\mathrm{O}_{\mathrm{a}}\right)$ & $\mathrm{cm}$ & $1.53(1.79)$ & 0 & 10 \\
Earthworm disturbance & $0-3$ index & $1.7(0.9)$ & 0 & 3 \\
\hline
\end{tabular}


Cyperaceae, and Juncaceae families) was estimated within four $1 \mathrm{~m}$ radius subplots in each plot. Graminoid cover was strongly dominated by Carex spp. (often $C$. pensylvanica), but also included contributions from other species, such as the grass Oryzopsis asperifolia. The occurrence and stem densities of nonnative shrub species (e.g., R. cathartica, Frangula alnus, and Lonicera tartarica) were measured in two size classes ( $<1 \mathrm{~m}$ and $\geq 1 \mathrm{~m}$ height) within a $5 \mathrm{~m}$ radius subplot. Mineral soil $\mathrm{pH}$ was determined using a water:soil suspension from aggregated samples of the upper $20 \mathrm{~cm}$ of mineral soil extracted from five random points within each plot.

We developed and implemented a rapid assessment technique to measure the disturbance severity of nonnative earthworm invasions. Direct sampling and processing of earthworms is time consuming and changes in earthworm activity levels during the growing season may cause inaccurate population estimates (Edwards 1991). Furthermore, our aim was to assess the disturbance caused by earthworms across a large region and relate this to other understory processes rather than to quantify the specific earthworm community. The disturbance severity ratings were based on evidence of earthworm activity, specifically changes to the organic and mineral soil horizons (Nielsen and Hole and Nielsen 1964; Hale et al. 2005a, b; Frelich et al. 2006; Holdsworth et al. 2007b; Loss et al. in Press). Multiple research sites within the study region with well documented earthworm communities and soil characteristics, including before and after earthworm invasion, were used to calibrate the disturbance severity ratings (Hale et al. 2005b; Holdsworth et al. 2007a). A similar rapid assessment approach in the same region by Loss et al. (in press) successfully used forest floor characteristics to identify invasion by specific nonnative earthworm species. Since we were measuring the severity of disturbance, ratings relate most to the impacts caused by anecic (e.g., L. terrestris) and epi-endogeic (e.g., $L$. rubellus) earthworm species which actively move among the soil layers and redistribute both organic and mineral particles (Holdsworth et al. 2007b Loss et al. In Press). The presence of epigeic species (e.g. $D$. octaedra), which cause very minor impacts to the forest floor (Hale et al. 2005b), would not by themselves cause a high severity rating.

In the field, each plot received a disturbance severity score on a scale from 0 to 3 , based on 5 factors: (1) thickness of organic soil horizons $\left(\mathrm{O}_{\mathrm{e}}\right.$ and $\mathrm{O}_{\mathrm{a}}$, excluding fresh litter); (2) exposure of mineral soil at the forest floor surface; (3) extent of mixing of organic and upper mineral soil horizons (formation of A horizon); (4) presence of castings and density of earthworm middens (organic material that accumulates at the entrances of L. terrestris burrows); and (5) detection of earthworms during collection of mineral soil samples. Sites with no evidence of earthworm disturbance (index $=0$ ) were characterized by thick $\mathrm{O}$ layer horizons ( $>5 \mathrm{~cm}$ thickness) with matted and bleached appearance, minimal exposed mineral soil $(<1 \%$ of plot area), and no physical signs of earthworm presence. Low levels of earthworm disturbance (index $=1$ ) included reduced $\mathrm{O}$ layer horizon thickness $(1-3 \mathrm{~cm})$, rare exposure of mineral soil ( $<5 \%$ of plot area), and few earthworms observed during soil sample collection. Evidence of moderate earthworm disturbance (index $=2$ ) included thin and patchy $\mathrm{O}$ horizon (typically $\leq 1 \mathrm{~cm}$ ), exposure of mineral soil (up to $50 \%$ ), mixing of organic and mineral soil and thus patchy development of an $\mathrm{A}$ horizon ( $<5 \mathrm{~cm}$ thickness), castings present and middens at low densities $\left(<1 / \mathrm{m}^{2}\right)$, and earthworms often found during soil collection. Sites heavily disturbed by nonnative earthworms (index $=3$ ) have a virtually absent $\mathrm{O}$ horizon and thus widespread exposure of mineral soil ( $>50 \%$ of plot area), well defined A horizon ( $>5 \mathrm{~cm}$ thickness), castings present and middens generally at densities $>1 / \mathrm{m}^{2}$, and earthworms often found during soil collection. Direct evidence of earthworms was used in the rating as corroborating evidence that disturbances were caused by earthworms and presence of middens piles was used because L. terrestris is associated with major changes to the soil environment (Hale et al. 2005a; Eisenhauer et al. 2012).

We used structural equation modeling (SEM) to investigate the relationships among environmental variables, disturbance severity of invasive earthworms, deer population size, cover of graminoid species, and browse pressure on seedlings. Our initial model was based on previous knowledge of individual relationships among environmental variables, earthworm disturbance, and deer (see "Introduction" for predicted relationships and respective references). Due to very low frequency of nonnative shrubs across the study sites (see "Results") and limited variance in soil texture within this forest type (data not shown), 
these factors could not be included in the model. SEM permits testing direct and indirect relationships between variables through a multivariate analysis (Grace 2006). In a SEM model, single-headed arrows represent direct causal relationships with the variable at the tail of the arrow representing the cause of the variable at the head. Double-headed arrows indicate unresolved relationships between two variables. For analyses, plot data were averaged to the site level. Model fits were assessed through $\chi^{2}$-tests (significant models have $p>0.05$ ) and model comparisons via AIC (Arbuckle 2010). Adequate models are indicated by non-significant $\chi^{2}$-tests $(p>0.05)$ (Grace 2006). The initial hypothesized model was improved based on model modification indices. Only scientifically sound relationships were considered and the best performing model (lowest AIC) is presented. SEM was performed using Amos 5 (Amos Development Corporation, Crawfordville, FL, USA).

\section{Results}

Evidence of disturbance by nonnative earthworms was found at sites across the study region (Fig. 1a). High or very high earthworm disturbance severity (mean site level rating $>1.8$ ) was found at $49 \%$ of sites, while only $18 \%$ of sites had evidence for very low disturbance (rating $<0.6$ ). Similarly, high browse pressure (index $=3$ ) was found at half of the sites and low browse (index $=1$ ) at only $23 \%$ of sites (Fig. 1b). The percent cover of graminoids, mainly
Fig. 1 Spatial patterning of a earthworm disturbance severity, b browse pressure on Acer spp. saplings, and c graminoid cover at forest study sites. Earthworm disturbance severity is based on soil characteristics and browse pressure on proportion of browsed stems (see "Methods") (a)

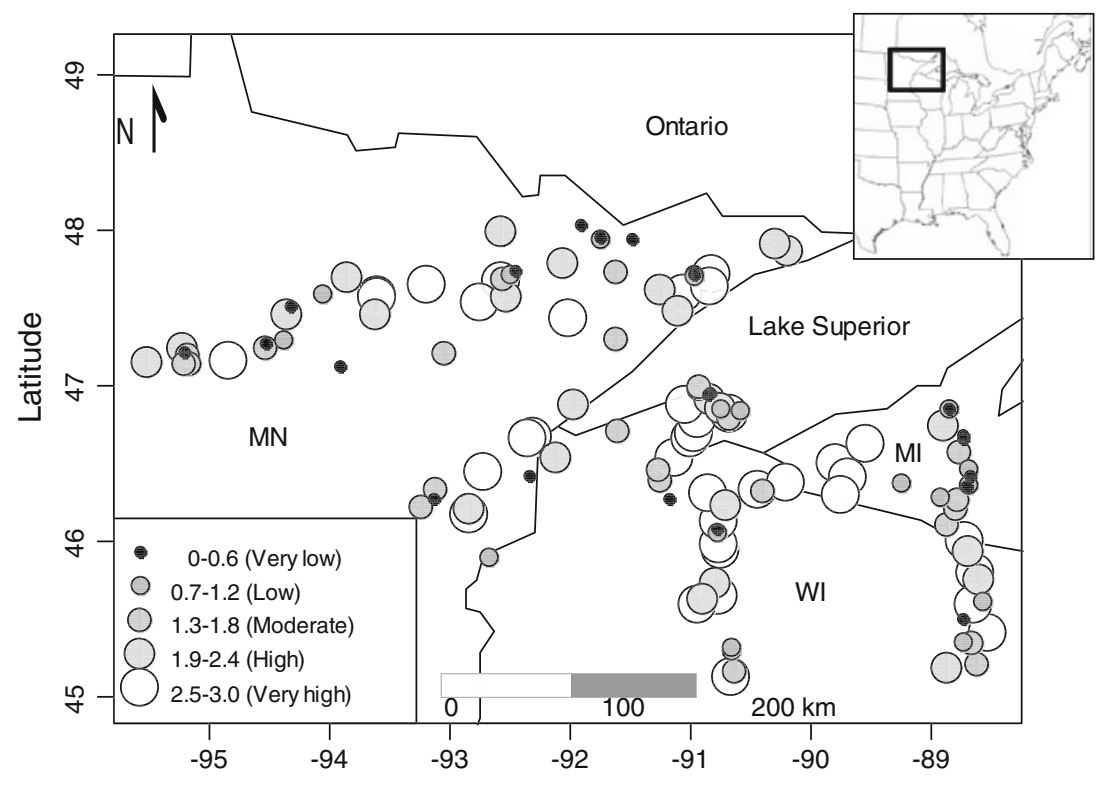

(b)



(c)

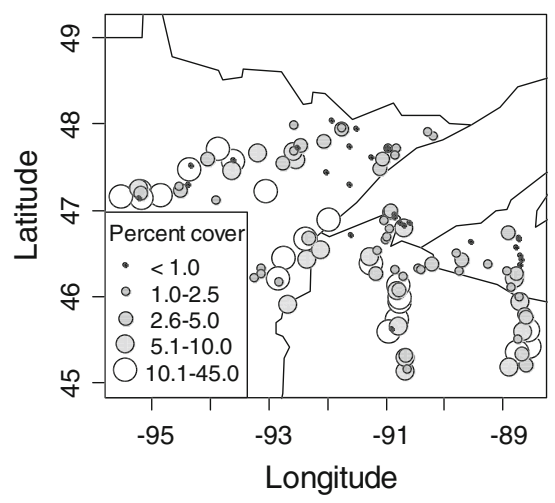


clonal sedges such as $C$. pensylvanica, varied from $<1 \%$ up to $45 \%$ and generally was highest at southern and western sites (Fig. 1c). In contrast, only two invasive nonnative shrub species ( $R$. cathartica and $F$. alnus) were found at a total of 4 sampling sites and on average comprised $<3 \%$ of woody understory stems $(<10 \mathrm{~cm} \mathrm{dbh})$ at these sites.

The initial hypothesized model (Fig. S1) fit the data well $\left(\chi_{13}^{2}=18.9, p=0.13\right.$, AIC $\left.=64.9\right)$, but could be improved modestly (Fig. $2 ; \chi_{15}^{2}=18.7, p=0.23$, AIC $=60.7$; see Table 2 for unstandardized estimates, critical ratios, and $p$ values) by removing pathways from temperature to graminoid cover, from temperature to earthworm disturbance severity, and from earthworm disturbance to browse pressure and by including the correlation between conifer basal area and annual precipitation. Overall, the model explained

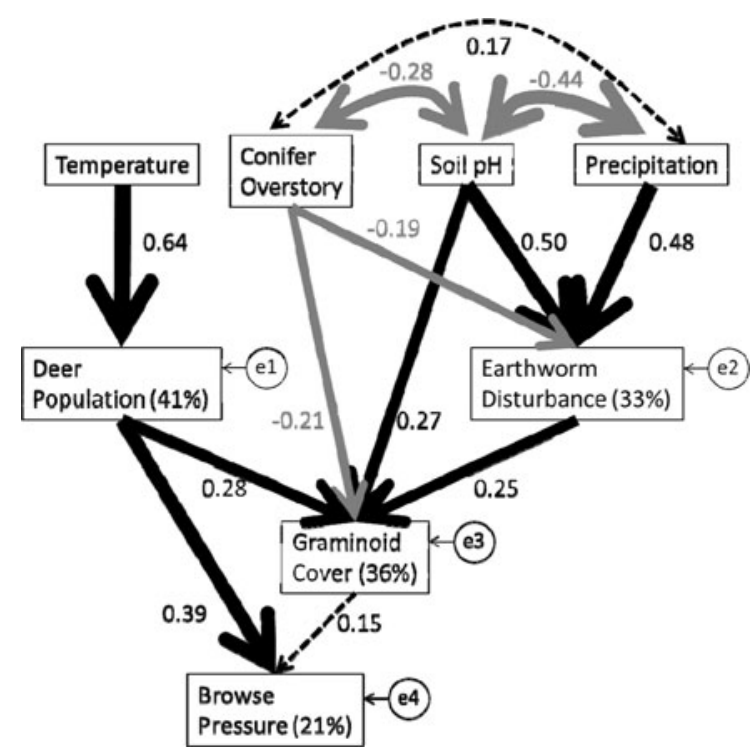

Fig. 2 Structural equation model (SEM) illustrating the direct and indirect relationships among environmental variables, nonnative earthworm disturbance severity, deer population density, graminoid cover, and browse pressure. The model fit the data well: $\chi_{15}^{2}=18.7, p=0.23$ (significant models have $p>0.05$ ). Numbers on the arrows are standardized path coefficients (equivalent to correlation coefficients, see Table 2 for unstandardized coefficients). Black solid arrows represent significant positive relationships and gray solid arrows show significant negative relationships $(p<0.05)$. Dashed arrows represent marginally significant relationships $(p \leq 0.1)$. Double-headed arrows show correlations between explanatory variables. Circles indicate error terms (e1-e4). Percentages in parentheses near endogenous variables are the variances explained by the model $\left(\mathrm{R}^{2}\right)$
$33 \%$ of the variance in earthworm disturbance severity, $36 \%$ of graminoid cover, and $21 \%$ of browse pressure. The two variables that most strongly influenced earthworm disturbance severity were soil $\mathrm{pH}$ and annual precipitation, and both had positive effects on earthworm disturbance. Overstory conifer basal area showed a moderately strong negative effect on earthworm disturbance. The only summer temperature relationship that was supported in the final SEM was the very strong positive pathway from temperature to deer population density. Graminoid cover increased with increasing deer density, soil $\mathrm{pH}$, and earthworm disturbance severity and had a direct negative relationship to conifer overstory abundance. Browse pressure on Acer stems increased strongly with deer density and showed a marginally significant $(p<0.1)$ positive relationship with graminoid cover.

Environmental variables also had indirect effects (calculated as the products of individual direct pathways) on graminoid cover and browse pressure through earthworm disturbance and deer population density. Soil $\mathrm{pH}$ and precipitation increased graminoid cover by increasing earthworm disturbance (indirect path coefficients $=0.13,0.12$, respectively). Conifer overstory abundance decreased graminoid cover by decreasing earthworm disturbance (indirect path coefficient $=-0.05)$. Temperature increased graminoid cover by increasing deer population density (indirect path coefficient $=0.18$ ), and temperature increased browse pressure by increasing deer populations (indirect path coefficient $=0.25$ ). Indirect pathways through graminoid cover to browse pressure were very weak due to the relatively weak direct effect of graminoid cover on browsing.

\section{Discussion}

High deer densities, with attendant chronic herbivory, and nonnative earthworms, which cause severe soil disturbance, are present at forest sites across the Great Lakes region. The presence of nonnative earthworms is known to depend on proximity to human developments, including forest roads, cabins, and fishing access points (Gundale et al. 2005; Tiunov et al. 2006; Holdsworth et al. 2007a). Our results indicate that, once introduced, the severity of earthworm disturbance is linked to stand characteristics, including litter quality, soil $\mathrm{pH}$, and precipitation, while deer density 
Table 2 Structural equation model (SEM) unstandardized path coefficients for the model in Fig. 2

\begin{tabular}{|c|c|c|c|c|}
\hline \multirow[t]{2}{*}{ Pathway } & \multicolumn{4}{|l|}{ Critical } \\
\hline & Estimate & SE & Ratio & $p$ value \\
\hline Worm disturbance $\leftarrow$ Conifer overstory & -0.033 & 0.013 & -2.488 & 0.013 \\
\hline Worm disturbance $\leftarrow$ Precipitation & 0.007 & 0.001 & 5.914 & $<0.001$ \\
\hline Worm disturbance $\leftarrow$ Soil $\mathrm{pH}$ & 1.091 & 0.182 & 5.996 & $<0.001$ \\
\hline (ln)Graminoids $\leftarrow$ Conifer overstory & -0.074 & 0.026 & -2.807 & 0.005 \\
\hline (ln)Graminoids $\leftarrow$ Deer $/ \mathrm{km}^{2}$ & 0.191 & 0.049 & 3.917 & $<0.001$ \\
\hline (ln)Graminoids $\leftarrow$ Soil $\mathrm{pH}$ & 1.144 & 0.334 & 3.423 & $<0.001$ \\
\hline (ln)Graminoids $\leftarrow$ Worm disturbance & 0.494 & 0.153 & 3.23 & 0.001 \\
\hline Browse $\leftarrow$ (ln)Graminoids & 0.065 & 0.036 & 1.795 & 0.073 \\
\hline Browse $\leftarrow$ Deer $/ \mathrm{km}^{2}$ & 0.115 & 0.025 & 4.697 & $<0.001$ \\
\hline Deer $/ \mathrm{km}^{2} \leftarrow$ Temperature & 2.648 & 0.288 & 9.207 & $<0.001$ \\
\hline Conifer overstory $\leftrightarrow$ Precipitation & 60.936 & 31.974 & 1.906 & 0.057 \\
\hline Conifer overstory $\leftrightarrow$ Soil pH & -0.654 & 0.220 & -2.968 & 0.003 \\
\hline Soil $\mathrm{pH} \leftrightarrow$ Precipitation & -12.485 & 2.790 & -4.475 & $<0.001$ \\
\hline
\end{tabular}

is positively related to temperature. Deer and earthworms have each been individually found to cause shifts in forest understory vegetation (Rooney and Waller 2003, Nuzzo et al. 2009). Through structural equation modeling, we were able to quantify such relationships for our 125 sites and show that deer and earthworms have very similar levels of impact on graminoid cover across this region. In addition, all four environmental variables had direct and/or indirect effects on graminoid cover and browse pressure, indicating that some forests, due to underlying environmental conditions, may be more prone to understory changes.

High to very high levels of earthworm disturbance were found at approximately half of the study sites (Fig. 1a). These mesic forests are likely especially conducive to high fitness of nonnative earthworms, due to large inputs of high quality leaf litter (e.g., A. saccharum and Tilia americana) and soils with relatively moderate $\mathrm{pH}$ and high moisture holding capacity (Frelich et al. 2006; Holdsworth et al. 2008). Inclusion of a broader variety of forest types, e.g., pine stands on acidic sandy outwash plains and lowland wet forests, would likely have shown stand characteristics to more strongly limit earthworm disturbance severity. Because we were unable to measure temporal aspects of invasion, such as time since first introduction, many sites may not have reached their maximum earthworm disturbance severity, thus accounting for some of the unexplained variance in the model.
Soil pH was often lower than 4.5 (study mean $=4.6$ ), the acidity level below which many earthworm communities start to become adversely affected (Nordström and Rundgren 1974). In addition to affecting the composition of the earthworm community, our results show that mineral soil acidity also affects the disturbance severity of nonnative earthworms. This is likely due to the fact that mainly soildwelling earthworm species (e.g., L. terrestris), causing the highest level of disturbance (e.g., Eisenhauer et al. 2007), are more detrimentally affected by low soil $\mathrm{pH}$, whereas litter-dwelling (epigeic) earthworms, which generally have more subtle disturbance effects, can occur in rather acidic stands. In addition to responding to soil $\mathrm{pH}$, earthworm activity can increase $\mathrm{pH}$ at the soil surface by bringing up and mixing baserich mineral soil from lower soil depths with surface organic material (Edwards 2004; Eisenhauer et al. 2007). However, our data did not support a causal relationship from earthworm disturbance to soil $\mathrm{pH}$ likely because we measured $\mathrm{pH}$ from samples comprised of the upper $20 \mathrm{~cm}$ of mineral soil and did not isolate and measure $\mathrm{pH}$ of the surface organic layer. Earthworm sensitivity to soil $\mathrm{pH}$ also indicates that in other areas with similar forest types but more acidic soils, such as the northeastern U.S. and neighboring Canada, earthworm disturbance severity may be more strongly curtailed.

Regional climate gradients showed direct relationships to deer density and earthworm disturbance and 
indirect effects on graminoid cover and browse damage. As this was an observational study, other unmeasured variables which closely correlate with summer temperature and annual precipitation may also be important factors influencing the forest understory. Higher deer densities at warmer sites are also related to land use practices and consequences such as agriculture and forest fragmentation. Annual precipitation was used as a proxy for site level moisture stress which is known to strongly limit earthworm activity (Curry 2004). Within site topographic position and soil depth and texture variability, not captured by our methods, also affect soil moisture and likely cause fine scale variation in earthworm disturbance. For example, lower slope positions with higher water tables and thus saturated soils for longer periods during the growing season may have fewer earthworms and less associated disturbance. Thin soils over bedrock would also be less likely to harbor deep burrowing earthworm species which cause much soil disturbance.

Due to the direct and indirect effects of temperature and precipitation, climate change is likely to impact several understory variables. The western edge of the study region is near the prairie-forest border and small changes in soil moisture, either increases or decreases, may strongly impact the health and regeneration of tree species (Frelich and Reich 2010) as well as the severity of earthworm activity. The past 30 years was a relatively wet period near the prairie-forest border (Karl et al. 2009), which may have exacerbated the disturbance severity of nonnative earthworms. Future climate predictions are for hotter and drier summers (Karl et al. 2009), which could reduce the activity of earthworm species and also adversely impact drought intolerant broadleaf species, such as $A$. saccharum, which produce high quality leaf litter. As deer approach their northern limits in the Great Lakes region, future warming may also facilitate population expansions (Côté et al. 2004) and their impacts on understory plant communities.

High graminoid cover in response to deer and earthworm disturbance is typically associated with decreases of other herbaceous species and tree seedlings (Hale et al. 2006; Holdsworth et al. 2007b). Clonal sedges (e.g., C. pensylvanica) seem especially suited to the consequences of earthworms and deer as they possess basal meristems and secondary compounds which reduce the incidence and severity of browse damage and most do not depend on mycorrhizal associations which can be disrupted by earthworm disturbance (Rooney and Waller 2003; Bohlen et al. 2004; Nuzzo et al. 2009). More detailed information on temporal shifts in plant community composition, seedling density, and earthworm disturbance and finer scale measures of deer activity are needed to shed light on the permanency of understory changes.

Somewhat surprisingly, nonnative shrubs were not abundant in the understory at study sites, which creates both a conservation opportunity as well as an imminent invasion risk. Invasive species, such as the shrubs $R$. cathartica, L. tatarica, and Rosa multiflora and herb Alliaria petiolata, are widely abundant at sites further south and their current absence from most study locations is likely due to temperature limitation and distance from source populations (e.g., disturbed areas around cities) (Kurtz 2010). Rising temperatures due to climate change may be the catalyst needed to add nonnative plant species to understories already altered by earthworms, deer, and graminoids.

Simply setting aside natural areas is not sufficient to protect biodiversity when other threats such as nonnative species and overabundant herbivores are present (Wiegmann and Waller 2006). This research characterizes an integrated set of key environmental variables directly affecting nonnative earthworm disturbance, facilitating predictions of the locations and severity of future earthworm disturbance, and the level of change in northern temperate and boreal forest ecosystems. Direct and indirect relationships among earthworms, deer, invasive plants (native and nonnative), and underlying environmental variables such as soil $\mathrm{pH}$, precipitation, litter quality, and temperature show that any management attempts to restore the native understory plant community will have to address multiple linked pathways.

Acknowledgments Financial support was provided by the U.S. Environmental Protection Agency's STAR Fellowship program; Hubachek Wilderness Research Foundation; University of Minnesota Wood-Rill Fellowship; DaytonWilkie Natural History Fund of the Bell Museum of Natural History; and University of Minnesota Carolyn Crosby Fellowship. N. Eisenhauer gratefully acknowledges funding by the Deutsche Forschungsgemeinschaft (DFG, German Research Foundation; Ei 862/1). We thank K. Riemersma, B. Wageman, and L. Miller for assistance with field work. 
Open Access This article is distributed under the terms of the Creative Commons Attribution License which permits any use, distribution, and reproduction in any medium, provided the original author(s) and the source are credited.

\section{References}

Alverson WS, Waller DM, Solheim SL (1988) Forests too deer: edge effects in northern Wisconsin. Conserv Biol 2: 348-358

Arbuckle JL (2010) IBM SPSS ${ }^{\circledR}$ Amos $^{\text {TM }} 19$ User's Guide. Amos Development Corporation, Crawfordville

Bohlen PJ, Groffman PM, Fahey TJ, Fisk MC, Suárez E, Pelletier DM, Fahey RT (2004) Ecosystem consequences of exotic earthworm invasion of north temperate forests. Ecosystems 7:1-12

Côté SD, Rooney TP, Tremblay JP, Dussault C, Waller DM (2004) Ecological impacts of deer overabundance. Annu Rev Ecol Evol Syst 35:113-147

Curry JP (2004) 6 factors affecting the abundance of earthworms in soils. In: Edwards CA (ed) Earthworm ecology, 2nd edn. CRC Press, Boca Raton, pp 91-113

Daly C, Halbleib M, Smith JI, Gibson WP, Doggett MK, Taylor GH, Curtis J, Pasteris PP (2008) Physiographically sensitive mapping of climatological temperature and precipitation across the conterminous United States. Int J Climatol 28:2031-2064

Edwards CA (1991) The assessment of populations of soilinhabiting invertebrates. Agric Ecosyst Environ 34: 145-176

Edwards CA (2004) Earthworm ecology. CRC Press, Boca Raton

Eisenhauer N (2010) The action of an animal ecosystem engineer: identification of the main mechanisms of earthworm impacts on soil microarthropods. Pedobiologia 53: 343-352

Eisenhauer N, Partsch S, Parkinson D, Scheu S (2007) Invasion of a deciduous forest by earthworms: changes in soil chemistry, microflora, microarthropods and vegetation. Soil Biol Biochem 39:1099-1110

Eisenhauer N, Fisichelli NA, Frelich LE, Reich PB (2012) Interactive effects of global warming and 'global worming' on the initial establishment of native and exotic herbaceous plant species. Oikos 121:1121-1133

Fisichelli NA, Frelich LE, Reich PB (2012a) Sapling growth responses to warmer temperatures 'cooled' by browse pressure. Glob Change Biol 18:3455-3463

Fisichelli NA, Frelich LE, Reich PB (2012b) Climate and interrelated tree regeneration drivers in mixed temperateboreal forests. Landscape Ecol. doi:10.1007/s10980-0129827-z

Frelich LE, Lorimer CG (1985) Current and predicted long-term effects of deer browsing in hemlock forests in Michigan, USA. Biol Conserv 34:99-120

Frelich LE, Reich PB (2010) Will environmental changes reinforce the impact of global warming on the prairie-forest border of central North America? Front Ecol Environ 8:371-378
Frelich LE, Hale CM, Scheu S, Holdsworth AR, Heneghan L, Bohlen PJ, Reich PB (2006) Earthworm invasion into previously earthworm-free temperate and boreal forests. Biol Invasions 8:1235-1245

Grace JB (2006) Structural equation modeling and natural systems. Cambridge University Press, Cambridge

Gundale MJ, Jolly WM, Deluca TH (2005) Susceptibility of a northern hardwood forest to exotic earthworm invasion. Conserv Biol 19:1075-1083

Hale CM, Frelich LE, Reich PB (2005a) Exotic European earthworm invasion dynamics in northern hardwood forests of Minnesota, USA. Ecol Appl 15:848-860

Hale CM, Frelich LE, Reich PB, Pastor J (2005b) Effects of European earthworm invasion on soil characteristics in northern hardwood forests of Minnesota, USA. Ecosystems 8:911-927

Hale CM, Frelich LE, Reich PB (2006) Changes in hardwood forest understory plant communities in response to European earthworm invasions. Ecology 87:1637-1649

Hendrix PF, Bohlen PJ (2002) Exotic earthworm invasions in North America: ecological and policy implications. Bioscience 52:801-811

Hendrix PF, Callaham MA Jr, Drake JM, Huang CY, James SW, Snyder BA, Zhang W (2008) Pandora's box contained bait: the global problem of introduced earthworms*. Annu Rev Ecol Syst 39:593-613

Holdsworth AR, Frelich LE, Reich PB (2007a) Regional extent of an ecosystem engineer: earthworm invasion in northern hardwood forests. Ecol Appl 17:1666-1677

Holdsworth AR, Frelich LE, Reich PB (2007b) Effects of earthworm invasion on plant species richness in northern hardwood forests. Conserv Biol 21:997-1008

Holdsworth AR, Frelich LE, Reich PB (2008) Litter decomposition in earthworm-invaded northern hardwood forests: role of invasion degree and litter chemistry. Ecoscience 15:536-544

Hole FD, Nielsen GA (1964) Earthworms and the development of coprogenous A1 horizons in forest soils of Wisconsin. Soil Sci Soc Am J 28:426-430

James SW, Hendrix PF (2004) Invasion of exotic earthworms into North America and other regions. In: Edwards CA (ed) Earthworm ecology, 2nd edn. CRC Press, Boca Raton, pp 75-88

Karl TR, Melillo JM, Peterson TC (2009) Global climate change impacts in the United States. Cambridge University Press, New York

Kurtz CM (2010) Effects of site and climate characteristics on forest invasibility by non-native plants in the Midwest. Thesis, University of Minnesota

Loss SR, Hueffmeier RM, Hale CM, Host GE, Sjerven G, Frelich LE (in press) A rapid method for assessing earthworm invasions in northern hardwood forests. Nat Areas J

McShea WJ, Rappole JH (1992) White-tailed deer as keystone species within forested habitats of Virginia. Va J Sci 43:1-77

Michigan Department of Natural Resources (MI DNR) (2006) Clickable-map of proposed 2006-2010 deer population goals. State of Michigan. http://www.michigan.gov/dnr/ 0,1607,7-153-10363_10856_10905-129948-,00.html

Minnesota Department of Natural Resources (MN DNR) (2009) 2009 Pre-fawn deer density from deer population model. 
State of Minnesota. http://files.dnr.state.mn.us/recreation/ hunting/deer/deer_density_prefawn_2009.pdf

Nordström S, Rundgren S (1974) Environmental factors and lumbricid associations in southern Sweden. Pedobiologia 14:1-27

Nuzzo VA, Maerz JC, Blossey B (2009) Earthworm invasion as the driving force behind plant invasion and community change in northeastern North American forests. Conserv Biol 23:966-974

Reich PB, Oleksyn J, Modrzynski J, Mrozinski P, Hobbie SE, Eissenstat DM, Chorover J, Chadwick OA, Hale CM, Tjoelker MG (2005) Linking litter calcium, earthworms and soil properties: a common garden test with 14 tree species. Ecol Lett 8:811-818

Rooney TP (2009) High white-tailed deer densities benefit graminoids and contribute to biotic homogenization of forest ground-layer vegetation. Plant Ecol 202:103-111
Rooney TP, Waller DM (2003) Direct and indirect effects of white-tailed deer in forest ecosystems. For Ecol Manag 181:165-176

Scheu S (2003) Effects of earthworms on plant growth: patterns and perspectives. Pedobiologia 47:846-856

Tiunov AV, Hale CM, Holdsworth AR, Vsevolodova-Perel TS (2006) Invasion patterns of Lumbricidae into the previously earthworm-free areas of northeastern Europe and the western Great Lakes region of North America. Biol Invasions 8:1223-1234

Wiegmann SM, Waller DM (2006) Fifty years of change in northern upland forest understories: identity and traits of "winner" and "loser" plant species. Biol Conserv 129:109-123

Wisconsin Department of Natural Resources (WI DNR) (2010) Deer abundance and densities in Wisconsin. State of Wisconsin. http://dnr.wi.gov/org/land/wildlife/hunt/deer/ maps.htm 